\title{
Transmission Effects' of Malay Food Knowledge
}

\author{
Mohd Shazali Md. Sharif1', Mohd Salehuddin Mohd Zahari', \\ Norazmir Md Nor ${ }^{2}$ \\ 1 Faculty of Hotel \& Tourism Management, \\ 2 Faculty of Health Sciences, \\ Universiti Teknologi MARA (UiTM), Puncak Alam, 42300 Selangor, Malaysia \\ shazali@salam.uitm.edu.my
}

\begin{abstract}
This study explored the effects of food transmission activities among the Malay ethnic's food knowledge and the generation practice. Mother and daughter were selected as an informant in this study. All information analyzed using thematic analysis. Commercialization of ingredients, convenience food products, economy, educational level and lifestyles apparently reduced the practices of Malay traditional foods among the young generations. Mothers, in particular, can play a significant role in preserving the practice of Malay traditional foods. Parents should ensure that the traditional food knowledge is passed down to their generations to ensure the Malay food tradition retains and evolves further.
\end{abstract}

Keywords: Malay ethnic; traditional food; food knowledge; food transmission

eISSN 2398-4295 @ 2018. The Authors. Published for AMER ABRA cE-Bs by e-International Publishing House, Ltd., UK. This is an open-access article under the CC BY-NC-ND license (http://creativecommons.org/licenses/bync-nd/4.0/). Peer-review under responsibility of AMER (Association of Malaysian Environment-Behaviour Researchers), ABRA (Association of Behavioural Researchers on Asians) and CE-Bs (Centre for EnvironmentBehaviour Studies), Faculty of Architecture, Planning \& Surveying, Universiti Teknologi MARA, Malaysia.

DOI: http://dx.doi.org/10.21834/ajbes.v3i10.94 


\subsection{Introduction}

Food can be seen as a midpoint of culture identity which belongs to a distinct society or ethnic and some elements of food preparation and consumption are the visible badges of identity (Rearick, 2009). Some argue preparation and consumption closely related to cultural of foods, the tools, techniques, and ingredients for which food is prepared, and it customs (Verbeke \& Lopez, 2005; Vu, 2009; Thomas, 2004) and this one of the best ways to understand a culture and ethnic identity (Scholliers, 2001). Food also acts as a symbol to the society and ethnic groups (Kittler \& Sucher, 2004). Crotty, I\& Germov (2004) demystified food through it preparation and consumption symbolize and mark the class structure of individual or society. Similarly, different ethnic having their religious beliefs and food play significantly in particular religious. Ing (2011) portray that food can be described as a part of the understanding of its function regarding the religion. Murphy (2000) in the different vein articulated that food in the feasts or celebrations symbolize values and bring significant meaning for cultures, ethnicity and religions.

Transferring the traditional food knowledge to the young generation is important to ensure the continuation of food culture evolves (Md. Nor et al., 2012; Mohd. Zahari, Kamaruddin, Muhammad, \& Kutut, 2011). There is no exception for the Malay traditional food. Modernization, particularly through technology and social advancement, believes in influencing the deskilling cooking knowledge and practices among the young Malays. There are significant concerns among nations about the potential loss in the context of traditional food knowledge and traditional food practices among the young generation. Traditional food represents the identity of ethic culture and food tradition that developed by many generations.

The United Nations through the International Workshop on Traditional Knowledge emphasizes that traditional food knowledge should continuously be retained for future generation as they will carry out the profound spiritual and identity for self or as Peoples (United Nations, 2007). Some ethnics are reported not only facing the problem of deskilling issue related to domestic cooking skills but start losing the traditional food culture owing to the weakening of old generation to past down the traditional cooking knowledge the young generations (Stringer, 2010; Bowen \& Devine, 2010). In Malaysia, preserving TFK or traditional food knowledge has received greater concern among the older generation, Malaysian Cultures Association and The Ministry of Information, Communication and Culture and others government agencies. The concerned of many parties on this issue raises critical questions of how the transfer of Traditional Food Knowledge occur in Malay ethnic related to typical daily food and how it has been passed down to the young generation. The main objective of this study is to investigate empirically the transferable process of Malay daily food knowledge concerning preparation, method and skills.

\subsection{Literature Review}

\section{Malay Ethnic}

Malays are an ethnic group of Austronesia people predominantly inhabiting the Malay Peninsula, including the southernmost parts of Thailand, the east coast of Sumatra, the coast 
of Borneo, and the smaller islands which lie between these locations (Mohamed, Mohamad, \& Hussain, 2010). The Malay ethnic group is distinct from the concept of a Malay race, which encompasses a wider group of people including the descendants of Indonesians, Philippines and people of Oceania (Hutton, 2000; Jalis, Zahari, Zulkifly, \& Othman, 2009). Malays traditionally had a close identification with Islam, and this religion remained ever since.

\section{Traditional Food}

Traditional food referred as foods that have been consumed for many generations which include all indigenous food plants found in that region or locality (The European Union, 2007). In other words, traditional foods are those foods originating locally in an area on the country, region, district or sub-district (Ohiokpehai, 2003). Some ingredients and traditional food preparation represent an intrinsic part of the identity of regional foods and by association with the people who consume them (Fajans, 2006). Jordana (2000) stated that traditional food is food that is differentiated through particular qualitative aspects and has a specific cultural identity while Kwik (2008) contended that traditional food may be interpreted as describing a process that does not change. It represents the collected wisdom of many generations of people who have learned how to produce and prepare food practiced by early generations to retain the tradition of the respective culture (Lyon, Colquhoun, \& Alexander, 2003).

\section{Traditional Food Knowledge}

Traditional food knowledge integrates some academic disciplines such as social, cultural, and nutritional anthropology; human ecology, agriculture, population health, family studies, community development, and education, among others (Warren, 2001). In human ecology, traditional food knowledge is systems that are being acknowledged as valuable in protecting the integrity of natural resources with regard to food (Egeland et al., 2009; Kuhnlein, Erasmus, \& Spigelski, 2009; Turner, Harvey, Burgess, \& V.Kuhnlein, 2009; V.Kuhnlein, Donald, Spigelski, Vittrekwa, \& Erasmus, 2009). In this context food knowledge is honed by generations of people in particular environments. Traditional food knowledge in ecology was used in Western communication since the late 1970s and early 1980s (V.Kuhnlein et al., 2009). In sum, ecology traditional food knowledge according to Warren (2001) is referred to knowledge generated by communities and ethnic groups that usually pass the knowledge from one generation to the next through oral transmission that focused on the microenvironment in which food is produced. Mohd Zahari et al., (2011) posited that cooking methods, food skills, and food decorum are inter-related and person-centered processes whereby it involved the set of competencies that are necessary to provide and prepare safe, nutritious, and culturally carry the value of traditional foods.

\section{Food Knowledge Transmission}

Over several decades, a transition or transmission in food preparation is observed to have a substantial impact on healthy eating Chenhall (2011). The individual behavior participates in the food preparations have to adjust to the healthy social environment, and modern technologies had simplified the food preparation processes (Engler \& Stringer, 2011). Chenhall (2011) further contended that most common challenges in transmitting and 
enhance cooking and food preparation skills among young generations within the context of families include time, individual/familial food choice. Despite these, limited literature has specifically uncovered the medium or elements that work along with food knowledge transmissions like food preparation, cooking method, cooking skill and food decorum (Bugge, 2003; Chenhall, 2011). The medium of food knowledge transmissions such as observing, hands-on learning (helper/assistance), recipe reading and practices are believed to be crucial elements in food transmission processes (Bugge, 2010; Kamaruddin, Zahari, Radzi, \& Ahmat, 2010; Langgat, Zahari, Yasin, \& Mansur, 2011; Short, 2003). Many scholars argue, in any transmission processes or before practices can be done, adaption on the matter concerned must be first occurred (Lang \& Caraher, 2001; Short, 2003; Warde, Cheng, Olsen, $\&$ Southerton, 2007). Adaptation, in fact, is a key that enabled humans to understand other individual's skills, knowledge, and experience. This approach opened the way for individual to familiarize and adjust the new knowledge gain which will lead or influence them to practice or utilize it (Cordes, 2004). In this context, food knowledge Adaptation is the evolutionary process by which an individual either remain, modifies or altered his cooking abilities and customs to fit into a current trend and demand (Boyd \& Richerson, 2006) and adaptation are closely associated with practices (Boyd \& Richerson, 2006). Chenhall (2011) identified five factors influencing the culture of cooking and food preparation practices within the home or domestic environment. This include:-

1. Increased availability of food commodities (basic/raw and processed);

2. Advances in technology for food storage, preparation, and cooking, resulting in changes in the level of knowledge and skill required to cook;

3. Shifting time and financial demands/ realities related to labor market participation;

4. Shifting family priorities and values; and

5. Decreased opportunities for cooking and food preparation skill acquisition both within the home and public education environments

\subsection{Methodology}

This study employs a qualitative approach to understanding the transmission issues of Malay traditional food knowledge. The rationale for conducting the qualitative study is because the information gathered provides an understanding of the process and the reasons for such behaviors rather than just determined using statistical procedures. The qualitative approach more subjective in nature and involve examining and reflecting on perception to gain an understanding of the social and human activities, that this research dealt with the elders' engagement of perceptions and ideas in the practice of traditional Malay food. The informant selection for this study was split into two generation involved with two generations, mother (age between 50 to 70 years old) and daughter (age between 20 to 40 years old) in a family selected as an informant. Malay settlement in Kuala Lumpur is the contextual setting for the study. All the information analyzed using thematic analysis. A set of open-ended interview questions developed to guide the informants to share their knowledge and experience in related to the transferable process of Malay cooking knowledge within generations. 
Table 1: Informants' Profiles

\begin{tabular}{|c|c|c|c|c|c|}
\hline Informant & Age & Education level & Occupation & $\begin{array}{l}\text { No. Of } \\
\text { children }\end{array}$ & $\begin{array}{l}\text { Origin } \\
\text { state }\end{array}$ \\
\hline \multicolumn{6}{|c|}{ Group Informant 1} \\
\hline $\begin{array}{l}\text { Mother } \\
\text { daughter }\end{array}$ & $\begin{array}{l}60 \\
39\end{array}$ & $\begin{array}{l}\text { Primary Level } \\
\text { Diploma }\end{array}$ & $\begin{array}{l}\text { Housewife } \\
\text { Bank } \\
\text { Admin. }\end{array}$ & $\begin{array}{l}6 \\
5\end{array}$ & $\begin{array}{l}\text { Johor } \\
\text { Selangor }\end{array}$ \\
\hline \multicolumn{6}{|c|}{ Group Informant 2} \\
\hline $\begin{array}{l}\text { Mother } \\
\text { daughter }\end{array}$ & $\begin{array}{l}64 \\
40\end{array}$ & $\begin{array}{l}\text { Primary Level } \\
\text { Diploma }\end{array}$ & $\begin{array}{l}\text { Housewife } \\
\text { Doctor }\end{array}$ & $\begin{array}{l}5 \\
3\end{array}$ & $\begin{array}{l}\text { Perak } \\
\text { Kuala } \\
\text { Lumpur }\end{array}$ \\
\hline \multicolumn{6}{|c|}{ Group Informant 3} \\
\hline $\begin{array}{l}\text { Mother } \\
\text { daughter }\end{array}$ & $\begin{array}{l}58 \\
33\end{array}$ & $\begin{array}{l}\text { Secondary Level } \\
\text { Diploma }\end{array}$ & $\begin{array}{l}\text { Retiree } \\
\text { Teacher }\end{array}$ & $\begin{array}{l}8 \\
3\end{array}$ & $\begin{array}{l}\text { Selangor } \\
\text { Kuala } \\
\text { Lumpur }\end{array}$ \\
\hline \multicolumn{6}{|c|}{ Group informant 4} \\
\hline $\begin{array}{l}\text { Mother } \\
\text { daughter }\end{array}$ & $\begin{array}{l}66 \\
33\end{array}$ & $\begin{array}{l}\text { Primary Level } \\
\text { STPM }\end{array}$ & $\begin{array}{l}\text { Housewife } \\
\text { Nurse }\end{array}$ & $\begin{array}{l}10 \\
3\end{array}$ & $\begin{array}{l}\text { Melaka } \\
\text { Selangor }\end{array}$ \\
\hline \multicolumn{6}{|c|}{ Group Informant 5} \\
\hline $\begin{array}{l}\text { Mother } \\
\text { daughter }\end{array}$ & $\begin{array}{l}59 \\
31\end{array}$ & $\begin{array}{l}\text { Secondary Level } \\
\text { Degree }\end{array}$ & $\begin{array}{l}\text { Housewife } \\
\text { Finance } \\
\text { Officer }\end{array}$ & $\begin{array}{l}6 \\
5\end{array}$ & $\begin{array}{l}\text { Kedah } \\
\text { Kuala } \\
\text { Lumpur }\end{array}$ \\
\hline
\end{tabular}

\subsection{Results and Discussions}

\section{The Transmission of Malay Traditional Foods Knowledge}

Based on the information gathered, the transmission of Malay traditional food knowledge within Malay ethnic generation does occur especially between mother and daughter. The process usually takes place once the daughters reach at aged seven years old and older. The findings also reveal that there is a variety of methods identified in the mode of knowledge transfer practiced by Malay ethnic families. Observation, be an assistant, received instruction and task from mothers are the common modes of knowledge transfer practiced in Malay ethnic families. The respondents further notified that the transmission of food knowledge occurred informally or without they are noticed it and what they usually remembered are their mothers always give instruction and command when they are required to be participating in the kitchen activities with her. Each Malay family has their method of preparing and cooking Malay traditional foods even though the name of the dish is similar. As the results there are many version of Asam pedas, Sambal Tumis, Masak Lemak Cili Padi, Masak Kari, Masak Kicap can be captured within Malay Ethnic families. Therefore, family members are the best party to carry the family food tradition through the food knowledge transfer to their young generations. Some the given answered obtained from both interviewed with mothers and daughters are presented in Table 2. 
Table 2: The Transmission Process

\begin{tabular}{|c|c|}
\hline Group Informant 1 & Answer \\
\hline Mother & $\begin{array}{l}\text { My mom start forces me to assist her in kitchen work when I was seven years } \\
\text { old. I usually was asked to peel the onion, garlic, and ginger. The instruction is } \\
\text { getting broader once I'm getting older. I gain food knowledge from assisting } \\
\text { my mother. }\end{array}$ \\
\hline Daughter & $\begin{array}{l}\text { My mom, always calls me to assist her in cooking activities once I reach ten } \\
\text { years old. She used to show me first before she allowed me to finish the rest. } \\
\text { I learn about cooking from what my mom had shown me. }\end{array}$ \\
\hline \multicolumn{2}{|l|}{ Group Informant 2} \\
\hline Mother & $\begin{array}{l}\text { My mother is so fierce, and I generally can only observe her do the cooking } \\
\text { while assisting her with the preparations before cooking. I improve my cooking } \\
\text { skill once I got married but in the same time, I have to adapt my husband and } \\
\text { my children food preference and taste. }\end{array}$ \\
\hline Daughter & $\begin{array}{l}\text { My mother always beside me while she instructed me with the preparation and } \\
\text { cooking task. In that way, she can easily monitor my performance and } \\
\text { corrected it instantly once she noticed it. I'm stressed up and could not } \\
\text { understand why she always wanted me to be with her in the kitchen while I'm } \\
\text { busy playing with my friends... }\end{array}$ \\
\hline
\end{tabular}

\section{The Adaptation of Malay Traditional Foods Knowledge of young generation}

The informants expressed that Malay children always acknowledge and admire their mother cooking especially once they are moving out. In this point, the children (especially the daughter) starts to replicate their mother cooking based on the observation or helping moment with their mother cooking in previous days. Some daughter adopts the knowledge gained while others adapted the knowledge gained from their mother due to the development of cooking technology and restriction of time to be in the kitchen for long hours. Marriage commitment also contributes to the adaptation of the family traditional foods like the adjustment of the spicy taste, the texture and the ingredients of the food due to the preference of the husbands and their kids. In this sense, it indicates that the adaptation of Malay traditional food knowledge depends on how the knowledge is transferred and the factors that influence the practice of the traditional food practice. Some the given answered obtained from both interviewed with mothers and daughters are presented in Table 3.

Table 3: The Adaptation Process

\begin{tabular}{|c|c|}
\hline Group Informant 3 & Answer \\
\hline Mother & $\begin{array}{l}\text { We used to cook food using firewood for years before we change to gasoline stove. } \\
\text { In the year 1980, my husband started to purchase gas stove...From this scenario, } \\
\text { I learned that the method of cooking our food is getting easier, faster and cleaner. } \\
\text { I can't forget how tedious in using the firewood for cooking; my cloth get smoky } \\
\text { smells, and my face gets blackish.... }\end{array}$ \\
\hline Daughter & $\begin{array}{l}\text { In my daily cooking l'Il make sure that l'll maintain the texture and taste of the } \\
\text { traditional food that I adapted from my mom's cooking and same as my husband } \\
\text { he will request me to adapt his mom cooking and her menu to be in our daily } \\
\text { cooking list. With regular practice of Malay traditional food, I feel that cooking this } \\
\text { food is not that severe as what other thought most important practice make } \\
\text { perfect... }\end{array}$ \\
\hline
\end{tabular}




\begin{tabular}{|c|c|}
\hline \multicolumn{2}{|c|}{ Group Informant 4} \\
\hline Mother & $\begin{array}{l}\text { In those time most mother's is house wife, they have ample time in the kitchen } \\
\text { compare to my generation we have to struggle with time to manage household } \\
\text { responsibilities and work duties. In another hand, we are lucky because the } \\
\text { availabilities of the convenience foods which aid to reduce the cooking period. }\end{array}$ \\
\hline Daughter & $\begin{array}{l}\text { My grandmother food preparation and cooking style was very detailed compared } \\
\text { to my mother. She used fresh ingredients and love to cook food from scratch. I } \\
\text { gain Malay traditional food knowledge more from my grandmother while my mother } \\
\text { shows me the simple (shortcut) way by using convenience ingredients, food } \\
\text { processor, and microwave oven. }\end{array}$ \\
\hline \multicolumn{2}{|c|}{ Group Informant 5} \\
\hline Mother & $\begin{array}{l}\text { Last time, in order to prepare Malay traditional meal we have to spend time } 2-3 \\
\text { hours for the preparations and cooking. The routine was so tiring because all the } \\
\text { preparation needs to be done manually... }\end{array}$ \\
\hline Daughter & $\begin{array}{l}\text { My mom, always told me that we are lucky because cooking routine and } \\
\text { preparation for Malay traditional foods are easier and even faster due to the } \\
\text { availability of food machinery and convenience foods in the market. }\end{array}$ \\
\hline
\end{tabular}

\section{The Factors that Effect Malay Traditional Food Practices to Young Generation}

All mothers to some extent agreed that some elements, without the doubt, had a significant impact on the young generation practices on the Malay food tradition. The majority of them pointed out that the advancement or modernization lessens the practices. In this context, they referred to the advancement or modernization as the process of change or transformation which involved education, entertainment, environment, and lifestyle. All of them admitted that they had gone through and experienced the changes. Some of the factors are lessening the practices among the young generation revealed during the interview sessions.

Most of the mothers strongly believe that technology through the commercialization of ingredients and convenience including Malay traditional foods has slightly altered the preparation (cooking equipment) as well as their consumption (eating utensils). The traditional ingredients had slightly changed due to the advancement of the food processing industry which enhances the varieties of new ingredients for Malay foods. The appearance of commercial ingredients in the market has also influenced the alterations. Various forms of improvised ingredients such as powders, sachets, frozen, chilled and dried ingredients are available for daily as well as festival food preparation. Social advancement (the economy, educational level, and lifestyles) is also an important factor moderating the alteration processes which lessening the practices among the young generation. The majority of them claimed to owe to working, and economic pressure limits the young generation engagement with kitchen work, therefore, lessening the practices of Malay traditional food.

Despite these, most mothers who involved in this study stressed that they are still preferred to use the traditional Malay ingredients and style of cooking although using the modern equipment. It is interesting also to note that all mothers bit worry concerning the commercialization of Malay food products which may result to the unfamiliarity of the traditional food among the later generations. Most of the daughters firmly admitted that they love their typical mother cooking, however, less able to practice accordingly owing to limited time and hectic working life. With that constraint, many revealed the lack of time, the distance 
of working place and tiring influence their traditional Malay cooking practices thus find an alternative for their family food. This was an evident when the majority of young mothers in this sample agreed that buying ready cooked food (bungkus/tapau) lessen their house duty, especially during weekdays. The most remarkable finding obtained from the young mothers is that they always combine simple traditional Malay cooking with convenience products for their family food which in turn decreasing the practices of typical Malay traditional food. Some the given answered obtained from both interviewed with mothers and daughters are presented in Table 4.

Table 4: Factors that Effect Malay Traditional Food Practices

\begin{tabular}{ll}
\hline Group Informant 3 & Answer \\
\hline Mother & Fast foods like KFC, McD, Pizza Hut have made the young generation more choice \\
& to choose for their daily meal. Previous days we don't even have a Malay \\
& Restaurant as much as today, and we normally can't afford to dine out with family. \\
\hline Daughter & There are many selections of food outlet available (from western food, Chinese \\
& food, Indian food, Thai food and Malay food) if we are unable to cook. Normally we \\
& can manage to dine out but we cannot do it as a routine because it might cost us \\
& a lot...To dine out with a family of four will cost us at least RM 50 - RM 200... \\
\hline Group Informant 4 & Answer \\
\hline Mother & $\begin{array}{l}\text { After working hours, most of us wanted to prepare meals as soon as possible... as } \\
\text { the results the convenience food become our preferred choice, it affordable, easy }\end{array}$ \\
\hline to prepare and fast... \\
\hline Daughter & $\begin{array}{l}\text { These days you can see how many families dining out and buy foods from } \\
\text { restaurants or food stalls to take away. Like myself, sometimes I also prefer buying } \\
\text { food from restaurants. Buy ready foods make my life less burden, and my kitchen } \\
\text { will be clean and tidy... }\end{array}$ \\
\hline Answer \\
\hline Mother & $\begin{array}{l}\text { Those days only one person in a family is working, so our income is limited, and } \\
\text { we can't afford to dine out... Like our family most of the fresh herbs and some local } \\
\text { vegetables we grew it in our back yard to reduce our food purchasing cost. } \\
\text { Furthermore, I'm not working... }\end{array}$ \\
\hline Daughter & $\begin{array}{l}\text { In future they (future generation) will not be familiar with our traditional dishes. } \\
\text { Everything is made simple for you....readymade product in the market; the } \\
\text { restaurants are selling variety dishes. This makes their life much easier. Slowly } \\
\text { they will lose their cooking skill. }\end{array}$ \\
\hline
\end{tabular}

\subsection{Conclusion}

Commercialization of ingredients, convenience food products, economy surroundings, educational level and lifestyles development apparently influenced and reduced the practices of Malay traditional foods among the young generations. Young generations always acknowledge and admire their mother cooking; therefore mothers, in particular, can play a significant role in preserving the practice of Malay traditional foods. Parents should ensure that the traditional food knowledge is passed down accordingly instead of unstructured or spontaneously to their generations to ensure the Malay food tradition retains and evolves further. Food knowledge transmission enables young generation to get connected with the traditional food practices that carried out from generation by generations. A lack of available 
studies looking at the transfer process in the Malaysian context means the insights and indepth understanding obtained from this study directly contribute to the global sociological food literature as well as to Malaysian food literature. In other words, the originality of this research will create or expand the Malaysian food body of knowledge and extend and enhance the gastronomic literature globally. Also, this study will also act as a benchmark and basis for the future and for other researchers to look further into this issue or other aspects of food-related cultural studies.

\section{Acknowledgement}

This research was supported financially by Ministry of Higher Education, Malaysia through Universiti Teknologi MARA under FRGS grant: 600-RMI/SSP/FRGS 5/3/Fsp (20/2011).

\section{References}

Boyd, R., \& Richerson, P. J. (2006). Culture, Adaptation, and Innateness. In: The Innate Mind: Culture and Cognition: eds.

Bugge, A. B. (2003). Cooking - As Identity Work. Paper presented at the The 6th Conference of the European Sociological Association, Murcia, Spain.

Bugge, A. B. (2010). Young people's school food styles. Young, 18(2), 223-243. doi: 10.1177/110330881001800206

Chenhall, C. (2011). Improving Cooking and Food Preparation Skills: A Synthesis of the Evidence to Inform Program and Policy Development (P.-C. P. H. Network, Trans.). Vancover Canada: Public Health Agency of Canada.

Cordes, C. (2004). The Human Adaptation for Culture and its Behavioral Implications. Journal of Bioeconomics, 6(2), 143-163. doi: 10.1023/B:JBIO.0000040408.87815.a9

Egeland, G. M., Roberts, G. C., Kuluguqtuq, J., Kilabuk, J., Okalik, L., Soueida, R., \& Kuhnlein, H. V. (2009). Back to the future: using traditional food and knowledge to promote a healthy future among Inuit Indigenous Peoples' food systems: the many dimensions of culture, diversity and environment for nutrition and health. Rome: Food and Agriculture Organization of the United Nations,.

Engler, R., \& Stringer. (2011). Food selection and preparation practices in a group of young low-income women in Montreal. [doi: DOI: 10.1016/j.appet.2010.12.004]. Appetite, 56(1), 118-121.

European Union. (2007). European Research on Traditional Foods. Belgium: Publications.europa.eu.

Fajans, J. (2006). Regional food and the tourist imigination in Brazil. Appetite, 47(3), 389.

Hutton, W. (2000). The food of Malaysia: Authentic recipes from the crossroads of Asia. Singapore. Singapore: Periplus edition (HK) Itd.

Jalis, M. H., Zahari, M. S., Zulkifly, M. I., \& Othman, Z. (2009). Malaysian gastronomic tourism products: Assessing the level of their acceptance among the western tourists. South Asian Journal of Tourism and Heritage, 2, 31-44.

Jordana, J. (2000). Traditional foods: challenges facing the European food industry. [doi: DOI: 10.1016/S09639969(00)00028-4]. Food Research International, 33(3-4), 147-152. 
Kamaruddin, M. S. Y., Zahari, M. S. M., Radzi, S. M., \& Ahmat, N. H. C. (2010). Modernization and Malay Matrimonial Foodways in the Rural Area. Paper presented at the TEAM Conference, Taylor's University.

Kuhnlein, H. V., Erasmus, B., \& Spigelski, D. (2009). Indigenous Peoples' food systems: the many dimensions of culture, diversity and environment for nutrition and health. Rome: Food and Agriculture Organization of the United Nations

Kwik, J. C. (2008). Traditional food knowledge: A case study of an Immigrant Canadian "foodscape". Environments, 36(1), 59-74.

Lang, T., \& Caraher, M. (2001). Is there a culinary skills transition? Data and debate from the UK about changes in cooking culture. Journal of the Australian Institute of Home Economics 8(2), 2-14.

Langgat, J., Zahari, M. S. M., Yasin, M. S., \& Mansur, N. A. (2011). The Alteration of Sarawak Ethnic Natives' Food: It's Impact to Sarawak State Tourism. Paper presented at the 2nd International Conference on Business and Economic Research

Lyon, P., Colquhoun, A., \& Alexander, E. (2003). Deskilling the domestic kitchen: national tragedy or the making of a modern myth? Food Service Technology 3, 167-175.

Md. Nor, N., Md. Sharif, M. S., Mohd. Zahari, M. S., Mohd. Salleh, H., Isha, N., \& Muhammad, R. (2012). The Transmission Modes of Malay Traditional Food Knowledge within Generations. Procedia - Social and Behavioral Sciences, 50(0), 79-88. doi: 10.1016/j.sbspro.2012.08.017

Mohamed, A. E., Mohamad, S., \& Hussain, H. (2010). Food gifts in Kelantanese Malay Weddings: Custom and Interpretation. Jurnal e-Bangi, 5(1), 103-115.

Mohd. Salehuddin, M. Z., Mohd. Syaquif, Y., Mohd. Zain, K., \& Langgat, J. (2011). The level of alteration of ethnic native food: A case of Sarawak, Malaysia. International Journal of Humanities and Social Science, 1(6), 137-145.

Mohd. Zahari, M. S., Kamaruddin, M. S. Y., Muhammad, R., \& Kutut, M. Z. (2011). Modernization, Malay Matrimonial Foodways and the Community Social Bonding. International Journal of Human and Social Sciences, 6(3), 10.

Ohiokpehai, O. (2003). Promoting the Nutritional Goodness of Traditional Food Products. Pakistan Journal of Nutrition, 2(4), 267-270.

Short, F. (2003). Domestic cooking practices and cooking skills: findings from an English study. Food Service Technology 3(4), 177-185.

Turner, N. J., Harvey, T., Burgess, S., \& V.Kuhnlein, H. (2009). The Nuxalk Food and Nutrition Program, coastal British Columbia, Canada: 1981--2006 Indigenous Peoples' food systems: the many dimensions of culture, diversity and environment for nutrition and health. Rome: Agriculture Organization of the United Nations.

V.Kuhnlein, H., Donald, M. M., Spigelski, D., Vittrekwa, E., \& Erasmus, B. (2009). Gwich'in traditional food for health: Phase 1 Indigenous Peoples' food systems: the many dimensions of culture, diversity and environment for nutrition and health. Rome: Agriculture Organization of the United Nations.

Warde, A., Cheng, S.-L., Olsen, W., \& Southerton, D. (2007). Changes in the Practice of Eating. Acta Sociologica, 50(4), 363-385. doi: 10.1177/0001699307083978

Warren, M. (2001). The role of the global network of indigenous knowledge resource centers in the conservation of cultural and biological diversity. In L. Maffi. (Ed.), On biocultural diversity (pp. 446-461). Washington: Smithsonian Institute Press. 